\title{
Synergy Of Top Management Team Characteristics, Corporate Governance And Social Responsibility: How Performance of Large Manufacturing Firms Changed
}

\author{
Julius Ogola Mugwang'a \\ Ph. D Candidate, School of Business, University of Nairobi \\ Zachary Bolo Awino \\ Professors of Strategic Management, University of Nairobi \\ Martin Ogutu \\ Professors of Strategic Management, University of Nairobi \\ Jackson Maalu \\ Professors of Strategic Management, University of Nairobi
}

\begin{abstract}
The study examines the joint effect of top management team characteristics, corporate governance and corporate social responsibility on organizational performance of large manufacturing firms. The study is guided by the upper echelons, agency, stakeholder and organizational performance theories respectively. A descriptive cross-sectional survey design was adopted. The population was all seventy two large manufacturing firms in Kenya. Primary data was collected using structured questionnaire from Chief Executive Officers. This was analysed through descriptive and multiple regression analysis. Results obtained show that the synergy of top management team characteristics, corporate governance and corporate social responsibility account for $47 \%$ of the performance of the firm. The results offer applicability and relevance of upper echelon, agency and stakeholder theories in normal organizational operations. While recruiting top managers, the selection board is guided to match the characteristic profiles of candidates against the members of the existing management team. In practice, firms attain superior performance if they incorporated good corporate governance with an independent board chairman, specialized board committees, and more outside directors on their boards. Organizations should mainstream corporate social responsibility practices that are consistent with expected societal expectations to stimulate higher performance. Policy makers are encouraged to be support manpower development, encourage improvement in governance and emphasize moral organizational value system as part of institutional conditions that impact on manufacturing performance in the local context as they formulate policies to aid competiveness of the sector projected in Kenya Vision 2030. The empirical testing in this paper adds to the scholarly knowledge by providing evidence on the synergistic effect of top management characteristics, corporate governance and social responsibility on firm performance. It goes further to contribute to literature on upper echelons theory, agency theory, stakeholder theory and organizational performance theory.
\end{abstract}

Key words: Top Management Team Characteristics, Corporate Governance, Corporate Social Responsibility, Organizational Performance, Large Manufacturing Firms

\section{INTRODUCTION}

Top managers structure decision situations to fit their view of the world. Identification of factors that direct or orient executive attention is essential in understanding organizational 
behaviour. These top managers possess distinct peculiarities and perceptions built through past know-how, learning and individual morals. These cognitions affect how top managers evaluate and react to circumstances and the manner decisions are arrived at in the organization with ultimate impact on organizational performance. This paper postulates that apart from demographic and psychological characteristics, behavioural factors like team cohesion, flexibility, open mindedness, extraversion, and conscientiousness including involvement in strategic decision-making have pronounced bearing on organizational performance.

Corporate growth leads to divergence and separation of ownership and control and for necessity, corporate governance structures are introduced to ensure the alignment of owners' and managers' economic interests. Fundamental to the corporate governance discussion is the understanding that a board of directors is the custodian of shareholders' interest (Dalton, Daily, Ellstrand \& Johnson, (1998). Several stakeholders have long advocated that, for effectiveness of boards (Monks \& Minow, 2001), structures should comprise, among others, the nomination of outsider directors, instituting special board committees and segregating the roles of CEO from those of the chairman of the board to monitor the actions of executives with a view to enhancing performance as well as ensuring environmental and social interests are addressed through corporate social responsibility (CSR).

Boards are supposed to define the CSR value-framework and to create the necessary reward and other incentives for motivating strong CSR responsibility performance. The executives are obviously in a situation to impact policy regarding formulation and implementation of CSR initiatives that go beyond minimum regulatory obligations to satisfy a wide range of stakeholders (Waldman \& Siegel, 2008). Such superior stakeholder satisfaction correlates with better corporate financial performance in the long run (Margolis \& Walsh, 2003; Jo \& Harjoto, 2011). Stakeholder approach encourages leaders to serve their stakeholders because these stakeholders hold the key to the firm's survival. Upper echelons theory (UET), on which TMT is anchored, holds that the decision to adopt CSR practices is rooted in an individuals' values and philosophies (Sherer \& Leblebici, 2001; Lepak, Taylor, Tekleab, Marrone \& Cohen, 2007).

Top managers are seen to be probable movers of CSR arising from the liberty they have in making strategic decisions and their roles in corporate social sensitivity (Swanson, 2008). This notwithstanding, their capability to effect CSR activities is dependent on amount of managerial freedom they have been given and the ethical guidance and inspiration of the top executive or CEO (Drucker, 1968). Corporate governance brings in board configuration and structure, to enhance the role of an organization's internal governance, improve the appreciation of the ways CSR schemes are developed and executed.

Manufacturing is regarded to be the basis of resilient and more lasting growth. However, manufacturers are faced with challenges; including swelling competition, unstable energy and input costs, new knowhow and supply chain visibility, (KPMG International Global Manufacturing Outlook, 2015). Manufacturing contributes around 12\% of Gross Domestic Product and employs about 300,000 people being $12 \%$ of employment in Kenya. The importance of this sector was emphasized when the Ministry of Industrialization and Enterprise Development launched Kenya's industrial transformation programme in September 2015 targeting 4 key areas: an increase of manufacturing to over 15 per cent of GDP, creation of 1 million jobs, a five-fold increase in Foreign Direct Investment and securing a top-50 position, from the current 143, in the Ease of Doing Business Index. 


\section{MATERIALS REVIEW}

Some previous studies in strategic management have shown that TMT characteristics have the ability to produce effective strategic decisions, generate superior creativity, and be more innovative in reaching more and different kinds of stakeholders, which ultimately impacts positively on firm performance (Mutuku, K'Obonyo \& Awino, 2013). The discussion on TMTs is anchored on the UET which articulates a model in which top executives and their backgrounds play essential role in determining major organizational outcomes (Hambrick \& Mason, 1984). Several studies, according to Niishi, Lepak, \& Schneider (2008), have sustained the relationship amongst upper echelon characteristics and organizational strategies and performance.

As much as it has been established that TMT characteristics have impact on organizational performance, corporate governance studies reveal owners' and managers' goals and desires are likely to conflict and could result in sub-optimal firm performance (Eisenhardt, 1989). Potential detrimental behaviors on the part of managers as a result of the principal-agent relationship include sub-optimal effort, perquisite consumption and the pursuit of "pet projects", under/over-investment (Brickley, Smith, \& Zimmerman, 2004), pursuing higher than optimal salary (Boyd, 1994), and unrelated diversification to reduce personal exposure to risk (Amihud \& Lev, 1981), among others. TMTs manage organizations as agents of the shareholders (principals), a relationship that is well articulated in the agency theory. As a firm grows, the shareholders of the company engage professional executives to help manage the company creating principal/agent relationship.

Corporate governance structure specifies the distribution of rights and responsibilities among different participants in the corporation, such as the board, managers, shareholders and other stakeholders, and spells out the rules and procedures for making decisions on corporate affairs. It encompasses board structure, which ideally should be composed of appropriate board size and clearly specifies the division of labour between the board, the CEO and other stakeholders (Finkelstein \& Hambrick, 1996). This enables the board to monitor the actions of management with a view to enhancing performance as well as enhancing environmental and social interests through CSR. As much as the board of directors is empowered with the critical obligation of guiding the moral culture of the firms they lead and their CSR alignment, the truth the emphasis placed on CSR by the board is dependent on the reporting responsibilities of the CEO and TMT.

Corporate social responsibility concept maintains that organizations have stakeholder groups that normally affect and are affected by them. Firms engage in CSR by deliberately engaging the activities that positively impact on employees, customers, suppliers, government and community at large. CSR engagement is seen to be closely associated with difficult ethical matters and is dependent on the capacity to perceive and work on stakeholder perspective (Lyons \& Dredge, 2006). Many studies have proved a positive relationship between CSR and consumer confidence (Swaene, 2001). Socially responsible behaviour has been found to allow a firm to differentiate its products in its market (Waddock \& Graves, 1997; McWilliams \& Siegel, 2001) hence, reducing the adverse effects of competition on organizational performance. In addition, CSR can enable an organization to minimize costly government-imposed fines (Shane \& Spicer, 1983; Freedman \& Stagliano, 1991) and can help in minimizing a firm's exposure to risk (Godfrey, 2004).

Kramer et al. (2006) argue that several companies use CSR to improve the reputation and company image, to strengthen the brand by demonstrating moral position and to improve the company's stock value. According to Kottler et al. (2005), companies use CSR activities to increase ability to attract, motivate and retain employees. CSR activities are also used to 
influence perception of investors and financial analysts enabling companies to access capital. CSR performance is closely related to complex ethical issues and is affected by the ability to observe and deal with stakeholder perspective (Lyons \& Dredge, 2006). Higher-educated top managers have been found to possess superior information processing and integration competency that enhance CSR performance (Li-Jen He, Chao-Jung Chen \& Hsaing-Tsai 2015). Shafer, Fukukawa and Lee (2007) argue that managers are required to first have the capacity to identify the prominence of stakeholder sensitivity on the success of the organization in order to take appropriate decisions allied to CSR.

Organizational performance represents the efficacy and effectiveness wherein the resources are put in use in effort to accomplish the organization's goals (Muchemi, 2013). Identifying the mission and purposes of the corporate including the methods they use to measure their achievement is central to the study of management (Drucker 1954; Ansoff 1965; Hofer and Schendel 1978; Schendel \& Hofer 1979; Andrews 1987). Irungu, (2007) contents that organizational results which provides the assessment of leadership and strategy is crucial for the existence of any organization. Machuki and Aosa (2011) argue that organization performance is a continuing subject in strategic management research.

Organizational performance frameworks incorporating long term goals and sustainability include Balanced Score Card (BSC) which suggests that performance be viewed against the four perspectives and cultivate metrics, gather data and evaluate it according to each of these perspectives. The four perspectives are the financial, customer, internal business processes, and learning and growth perspectives. The BSC context enables interpreting strategy into objectives and initiatives across the four perspectives. BSC considers different dimensions of stakeholders which is in line with the stakeholder theory that requires measurement of organization's performance compared to the anticipations of various interested party groups and individuals that are impacted or impact on organizational activities. Additionally, Kaplan (1983) suggests a solution to the challenge related to the extent of manufacturing performance by holding that senior management should develop indicators that nurture long term effectiveness and success and do away with short term financial processes based on manufacturing traditions of regularization.

The overall objective of the paper was to determine the joint effect of top management team characteristics, corporate governance and corporate social responsibility on organizational performance of large manufacturing firms in Kenya. To achieve this objective a number of hypotheses were tested.

$\boldsymbol{H}_{1}$ : The joint effect of TMT characteristics, corporate governance and corporate social responsibility on organizational performance is not statistically significant.

$\boldsymbol{H}_{1} \boldsymbol{a}$ : The joint effect of TMT characteristics, corporate governance and corporate social responsibility has no significant influence on financial performance

$\boldsymbol{H}_{1} \boldsymbol{b}$ : The relationship between TMT characteristics, corporate governance and corporate social responsibility on customer perspective is not statistically significant

$\boldsymbol{H}_{1} \boldsymbol{c}$ : The joint effect of TMT characteristics, corporate governance and corporate social responsibility on internal business processes is not statistically significant.

$\boldsymbol{H}_{1 d}$ : The joint effect of TMT characteristics, corporate governance and corporate social responsibility on learning and growth is not statistically significant.

\section{METHODS AND RESULTS}

We analysed data from 56 large manufacturing firms in Kenya who were members of KAM in the year 2016. The important respondents were top managers charged with oversight roles on 
performance management. Specifically, the questionnaire was handled by the respective CEO or other senior officer delegated. The firms covered spread across building, mining \& construction; chemical \& allied; energy, electrical \& electronics; food \& beverages; leather \& footwear; metal \& allied; paper \& board; pharmaceutical \& medical equipment; plastics \& rubber; textiles \& apparels; sub-sectors and appear on the list of Kenya Revenue Authority's list of large tax payers. Manufacturing sector contributes around 12\% of Gross Domestic Product and employs about 300,000 people being $12 \%$ of employment in Kenya. Over the years, the relative size of the sector has been stagnant, it has lost market share abroad, and it is struggling with structural inefficiencies. Low overall throughput and huge productivity variances in firms across subsectors point to absence of competitive advantage (KAM, 2015). The data was analysed using correlation and regression analysis.

The study conducted Pearson correlation analysis to indicate a linear association among the predictor variables and the results are shown in table 1.

Table 1: Correlation Matrix of Study Variables Correlations

\begin{tabular}{|ll|r|r|r|}
\hline & & TMT_characteristics & $\begin{array}{c}\text { Corporate_Social_ } \\
\text { Responsibility }\end{array}$ & $\begin{array}{c}\text { Corporate_ } \\
\text { Governance }\end{array}$ \\
\hline TMT_characteristics & Pearson Correlation & 1 & $.506^{* *}$ & $.739^{* *}$ \\
& Sig. (2-tailed) & .000 & .000 \\
& $\mathrm{~N}$ & 56 & 55 \\
\hline Corporate_Social_Responsib & Pearson Correlation & $.506^{* *}$ & 1 \\
ility & Sig. (2-tailed) & .000 & $.627^{* *}$ \\
& $\mathrm{~N}$ & 55 & .000 \\
\hline Corporate_Governance & Pearson Correlation & $.739^{* *}$ & 54 \\
& Sig. (2-tailed) & .000 & 55 \\
& $\mathrm{~N}$ & 55 & $.627^{* *}$ \\
& & .000 & 54 \\
\hline
\end{tabular}

**. Correlation is significant at the 0.01 level (2-tailed).

The correlation results shown in Table 1 indicate that there is a positive relationship between TMT characteristics and CSR as indicated by a correlation value a positive of 0.506 . The correlation between TMT characteristics and corporate governance is highest at 0.738 , while the correlation between CSR and corporate governance is at 0.627 . All the relationships were statistically significant with p-value 0.000 being less than 0.05 . All the coefficients of the variables in this paper were not highly correlated.

To test hypotheses multiple regression was carried out first on overall performance then on individual measures of organizational performance. This formed the basis for which the decision to accept or reject the hypothesis was made. Table 2 presents the regression model of the combined effects of top management team characteristics, corporate governance and CSR on organizational performance. 
Table 2: TMT Characteristics, Corporate Governance, CSR and Organizational Performance

\begin{tabular}{|c|c|c|c|c|c|c|c|c|}
\hline \multicolumn{9}{|c|}{ Model Summaryb } \\
\hline $\begin{array}{l}\text { Mode } \\
\text { l }\end{array}$ & $\mathrm{R}$ & R Square & \multicolumn{2}{|c|}{$\begin{array}{l}\text { Adjusted R } \\
\text { Square }\end{array}$} & $\begin{array}{l}\text { Std. Error of } \\
\text { the Estimate }\end{array}$ & \multicolumn{3}{|c|}{ Durbin-Watson } \\
\hline 1 & $.686^{\mathrm{a}}$ & .470 & \multicolumn{3}{|r|}{.44252} & \multicolumn{3}{|r|}{1.825} \\
\hline \multicolumn{9}{|c|}{ a. Predictors: (Constant), Corporate_Governance, Corporate_Social_Responsibility, TMT_characteristics } \\
\hline \multicolumn{9}{|c|}{ b. Dependent Variable: Organizational_Performance } \\
\hline \multicolumn{9}{|c|}{ ANOVAa $^{a}$} \\
\hline \multicolumn{2}{|l|}{ Model } & \multicolumn{2}{|c|}{$\begin{array}{c}\text { Sum of } \\
\text { Squares }\end{array}$} & df & Mean Square & $\mathrm{F}$ & \multicolumn{2}{|c|}{ Sig. } \\
\hline \multirow[t]{3}{*}{1} & Regression & \multicolumn{2}{|c|}{8.686} & 3 & 2.895 & 14.786 & \multicolumn{2}{|r|}{$.000^{\mathrm{b}}$} \\
\hline & Residual & \multicolumn{2}{|c|}{9.791} & 50 & .196 & & & \\
\hline & Total & \multicolumn{2}{|c|}{18.477} & 53 & & & & \\
\hline \multicolumn{9}{|c|}{ a. Dependent Variable: Organizational_Performance } \\
\hline \multirow{2}{*}{\multicolumn{9}{|c|}{ b. Predictors: (Constant), Corporate_Governance, Corporate_Social }} \\
\hline & & & & & & & & \\
\hline \multirow[t]{2}{*}{ Model } & 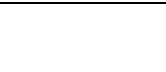 & (2) & \multicolumn{3}{|c|}{ Unstandardized Coefficients } & \multirow{2}{*}{$\begin{array}{c}\begin{array}{c}\text { Standardized } \\
\text { Coefficients }\end{array} \\
\text { Beta }\end{array}$} & $\mathrm{t}$ & \multirow[t]{2}{*}{ Sig. } \\
\hline & & & & $\mathrm{B}$ & Std. Error & & & \\
\hline \multirow[t]{4}{*}{1} & \multicolumn{3}{|l|}{ (Constant) } & 1.972 & .683 & 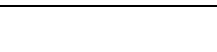 & 2.889 & .006 \\
\hline & \multirow{2}{*}{\multicolumn{2}{|c|}{$\begin{array}{l}\text { TMT_characteristics } \\
\text { Corporate_Social_Responsi } \\
\text { bility }\end{array}$}} & & -.270 & .255 & -.158 & -1.060 & .294 \\
\hline & & & & .326 & .115 & .377 & 2.839 & .007 \\
\hline & \multicolumn{2}{|c|}{ Corporate_Governance } & & .436 & .146 & .493 & 2.987 & .004 \\
\hline
\end{tabular}

Table 2 presented the regression model goodness of fit on TMT characteristics, corporate governance, CSR and organizational performance. An R-square value of 0.470 was established depicting that the relationship was significant and that TMT characteristics, corporate governance and corporate social responsibility accounts for $47.0 \%$ of the organizational performance of the large manufacturing firms. The relationship is strong with $\mathrm{R}$ value of 0.686 and statistically significant $\mathrm{P}$-value $0.000<0.05$. The study established the following regression model:

Organizational Performance $=1.972-.270^{*}$ TMT characteristics $+.326^{*}$ CSR $^{*}+.436^{*}$ Corporate governance

The study established that when TMT characteristics, CSR and governance are zero, and organizational performance would be at 1.972. From the coefficients, it was noted TMT characteristics, corporate governance and CSR are significant in explaining organizational performance of the large manufacturing firms. TMT characteristics variable had $\beta=-0.270$ meaning that as TMT characteristics increase, organizational performance decreases by 0.270 units. It also has t-value of -1.060 , and a p-value of -0.294 .

In contrast corporate governance has a beta value of $\beta=0.436$ implying that a unit increase in corporate governance yields 0.436 positive increases in organizational performance. The relationship between corporate governance and organizational performance is statistically significant at $t$-value of 2.987 with $p$-value of $0.004<0.05$. Likewise CSR has a beta value of $\beta=$ 0.326 implying that one unit change in corporate governance yields 0.326 positive change in organizational performance. The relationship between corporate governance and organizational performance is statistically significant at t-value of 2.839 with $p$-value of $0.007<$ 0.05 . 


\section{TMT Characteristics, Corporate governance, CSR and Financial Performance}

The results of the analysis done to establish the joint effect of top management team characteristics, corporate governance, and corporate social responsibility on financial performance are presented in Table 3.

Table 3: Joint effect of TMT Characteristics, Corporate governance, and CSR on financial performance

\begin{tabular}{|c|c|c|c|c|c|c|c|c|}
\hline \multicolumn{9}{|c|}{ Model Summaryb } \\
\hline $\begin{array}{l}\text { Mode } \\
\text { l }\end{array}$ & $\mathrm{R}$ & R Square & \multicolumn{2}{|c|}{$\begin{array}{l}\text { Adjusted R } \\
\text { Square }\end{array}$} & $\begin{array}{l}\text { Std. Error of } \\
\text { the Estimate }\end{array}$ & \multicolumn{3}{|c|}{ Durbin-Watson } \\
\hline 1 & $.514^{\mathrm{a}}$ & .265 & \multicolumn{2}{|r|}{.220} & .67529 & \multicolumn{3}{|r|}{1.785} \\
\hline \multicolumn{9}{|c|}{ a. Predictors: (Constant), Corporate_Governance, Corporate_Social_Responsibility, TMT_characteristics } \\
\hline \multicolumn{9}{|c|}{ b. Dependent Variable: Financial_Performance } \\
\hline \multicolumn{9}{|c|}{ ANOVAa } \\
\hline \multicolumn{2}{|l|}{ Model } & \multicolumn{2}{|c|}{$\begin{array}{c}\text { Sum of } \\
\text { Squares }\end{array}$} & df & Mean Square & $\mathrm{F}$ & \multicolumn{2}{|c|}{ Sig. } \\
\hline \multirow[t]{3}{*}{1} & Regression & \multicolumn{2}{|c|}{8.041} & 3 & 2.680 & 5.878 & \multicolumn{2}{|r|}{$.002^{\mathrm{b}}$} \\
\hline & Residual & \multicolumn{2}{|c|}{22.345} & 49 & .456 & & & \\
\hline & Total & \multicolumn{2}{|c|}{30.386} & 52 & & & & \\
\hline \multicolumn{9}{|c|}{ a. Dependent Variable: Financial_Performance } \\
\hline \multirow{2}{*}{\multicolumn{9}{|c|}{$\begin{array}{r}\text { b. Predictors: (Constant), Corporate_Governance, Corporate_Social } \\
\text { Coefficients }{ }^{\mathbf{a}}\end{array}$}} \\
\hline & & & & & & & & \\
\hline \multirow[t]{2}{*}{ Model } & 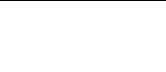 & 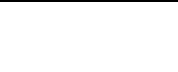 & \multicolumn{3}{|c|}{ Unstandardized Coefficients } & \multirow{2}{*}{$\begin{array}{c}\begin{array}{c}\text { Standardized } \\
\text { Coefficients }\end{array} \\
\text { Beta }\end{array}$} & $\mathrm{t}$ & \multirow[t]{2}{*}{ Sig. } \\
\hline & & & & $\mathrm{B}$ & Std. Error & & & \\
\hline \multirow[t]{4}{*}{1} & \multicolumn{2}{|l|}{ (Constant) } & & 1.718 & 1.078 & & 1.593 & .118 \\
\hline & \multirow{2}{*}{\multicolumn{2}{|c|}{$\begin{array}{l}\text { TMT_characteristics } \\
\text { Corporate_Social_Responsi } \\
\text { bility }\end{array}$}} & & -.165 & .400 & -.072 & -.411 & .683 \\
\hline & & & & .042 & .176 & .038 & .240 & .811 \\
\hline & \multicolumn{2}{|c|}{ Corporate_Governance } & & .621 & .223 & .539 & 2.786 & .008 \\
\hline
\end{tabular}

Table 3 above presented the regression model goodness of fit on TMT characteristics, corporate governance, CSR and financial performance. R value of 0.514 was established depicting that the joint effect had a positive linear relationship with financial performance, and the relationship is statistically significant with p-value $0.002<0.05$. An R-square value of 0.265 was established depicting that TMT characteristics, corporate governance and CSR accounts for $26.5 \%$ of the financial performance of the large manufacturing firms. The study established the following regression model:

Organizational Performance $=1.718-.165^{*} \mathrm{TMT}$ characteristics $+.042^{*} \mathrm{CSR}^{*}+.621 *$ Corporate governance

The study established that when TMT characteristics, CSR and corporate governance are zero, and financial performance would be at 1.718. The study also established that holding other factors constant, a unit increase in TMT characteristics would yield .165 decrease in financial performance, a unit increase in CSR would yield .042 increase in financial performance while a unit increase in corporate governance would yield .621 increase in financial performance.

\section{TMT, Corporate governance, CSR and Customer Service}

The results of the analysis done to establish the joint effect of Top Management Team characteristics, corporate governance, and CSR on customer service are presented in table 4. 
Table 4: Joint effect of TMT Characteristics, Corporate Governance, and CSR on Customer Perspective

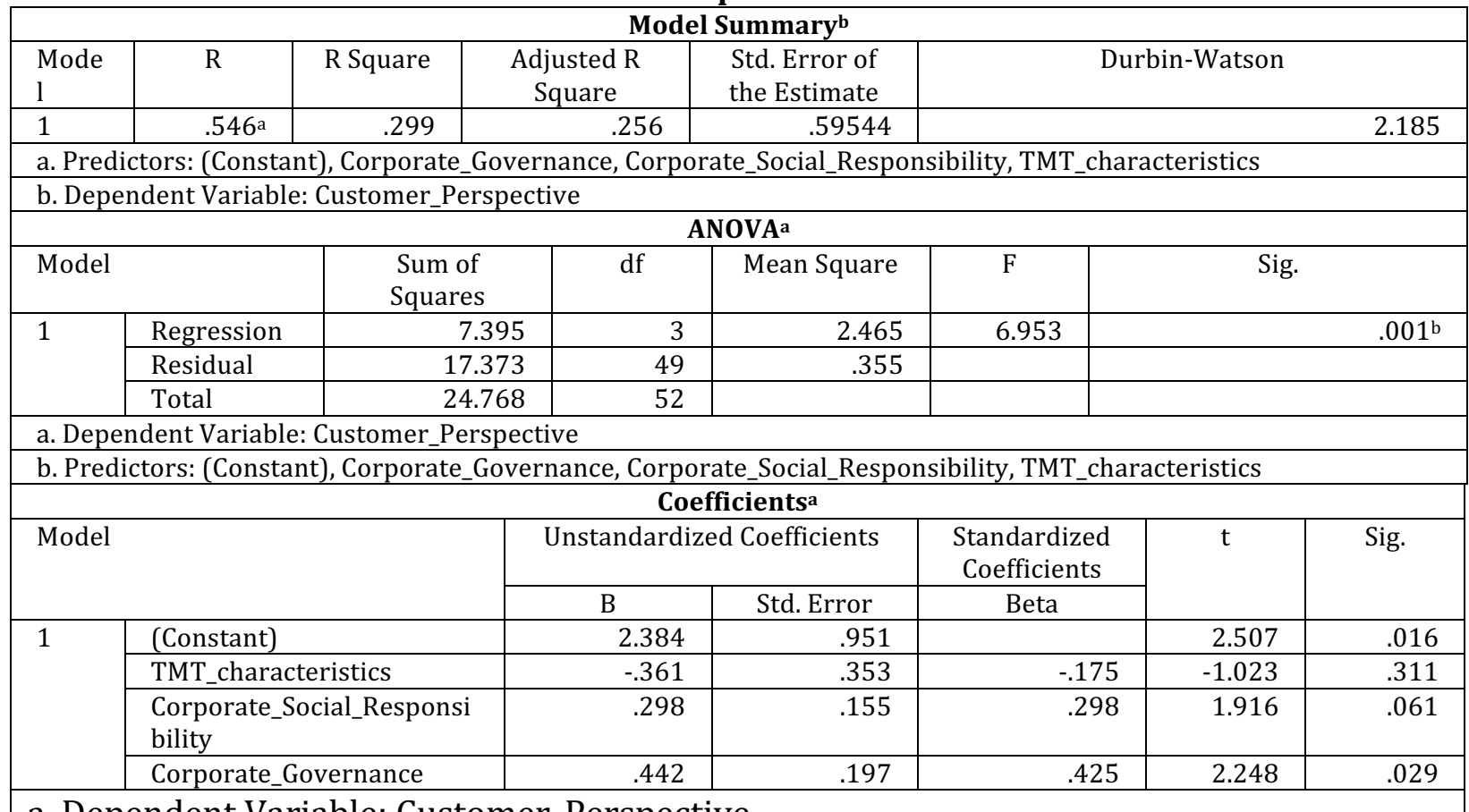

a. Dependent Variable: Customer_Perspective

Table 4 presented the regression model goodness of fit on TMT characteristics, corporate governance, and CSR on customer perspective. R value of 0.546 was established depicting that the relationship was moderately positive. An R-square value of 0.299 was established depicting that the relationship was significant and that TMT characteristics, corporate governance and CSR jointly account for $29.9 \%$ of the customer perspective of the large manufacturing firms. The F statistic of this model was 6.953 and $p$ value was 0.001 . The $p$ value being less than 0.05 , the model was established to be statistically significant at 95 percent confidence level.

\section{TMT, Corporate governance, CSR and Internal Business Processes Perspective}

The results of the analysis done to establish the combined effect of TMT characteristics, corporate governance, and CSR on internal business processes are presented in Table 5. 
Table 5: Joint effect of TMT Characteristics, Corporate governance and CSR on internal business processes perspective

\begin{tabular}{|c|c|c|c|c|c|c|c|c|}
\hline \multicolumn{9}{|c|}{ Model Summaryb } \\
\hline $\begin{array}{l}\text { Mode } \\
\text { l }\end{array}$ & $\mathrm{R}$ & R Square & \multicolumn{2}{|c|}{$\begin{array}{ll}\text { Adjusted } & \mathrm{R} \\
\text { Square } & \end{array}$} & $\begin{array}{l}\text { Std. Error of } \\
\text { the Estimate }\end{array}$ & \multicolumn{3}{|l|}{ Durbin-Watson } \\
\hline 1 & $.666^{\mathrm{a}}$ & .443 & \multicolumn{2}{|c|}{.410} & .55256 & \multicolumn{3}{|l|}{1.910} \\
\hline \multicolumn{9}{|c|}{ a. Predictors: (Constant), Corporate_Governance, Corporate_Social_Responsibility, TMT_characteristics } \\
\hline \multicolumn{9}{|c|}{ b. Dependent Variable: Internal_business_processes } \\
\hline \multicolumn{9}{|c|}{ ANOVAa } \\
\hline \multicolumn{2}{|l|}{ Model } & \multicolumn{2}{|c|}{$\begin{array}{l}\text { Sum of } \\
\text { Squares }\end{array}$} & $\mathrm{df}$ & Mean Square & $\mathrm{F}$ & \multicolumn{2}{|c|}{ Sig. } \\
\hline \multirow[t]{3}{*}{1} & Regression & \multicolumn{2}{|c|}{12.160} & 3 & 4.053 & 13.275 & & $.000^{\mathrm{b}}$ \\
\hline & Residual & \multicolumn{2}{|c|}{15.266} & 50 & .305 & & & \\
\hline & Total & \multicolumn{2}{|c|}{27.426} & 53 & & & & \\
\hline \multicolumn{9}{|c|}{ a. Dependent Variable: Internal_business_processes } \\
\hline \multirow{2}{*}{\multicolumn{9}{|c|}{$\begin{array}{r}\text { b. Predictors: (Constant), Corporate_Governance, Corporate_Social } \\
\text { Coefficients }\end{array}$}} \\
\hline & & & & & & & & \\
\hline \multirow[t]{2}{*}{ Model } & 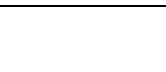 & 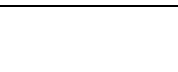 & \multicolumn{3}{|c|}{ Unstandardized Coefficients } & \multirow{2}{*}{$\begin{array}{c}\begin{array}{c}\text { Standardized } \\
\text { Coefficients }\end{array} \\
\text { Beta }\end{array}$} & $\mathrm{t}$ & Sig. \\
\hline & & & & B & Std. Error & & & \\
\hline \multirow[t]{4}{*}{1} & (Constant) & & & 2.216 & .852 & & 2.599 & .012 \\
\hline & TMT_charac & eristics & & -.525 & .318 & -.253 & -1.650 & .105 \\
\hline & $\begin{array}{l}\text { Corporate_S } \\
\text { bility }\end{array}$ & cial_Responsi & & .405 & .143 & .385 & 2.826 & .007 \\
\hline & Corporate $\mathrm{c}$ & vernance & & .560 & .182 & .519 & 3.067 & .003 \\
\hline
\end{tabular}

Table 5 shows the results of the joint effect of TMT characteristics, CSR and corporate governance had a strong positive relationship $(\mathrm{R}=0.666)$ on internal business processes explaining 44.3 percent of variation on internal business processes of large manufacturing firms $\left(\mathrm{R}^{2}=0.443\right)$. The $\mathrm{F}$ statistic of this model was 13.275 and $p$ value $0.000<0.05$ meaning the model was established to be statistically significant at 95 percent confidence level.

\section{TMT Characteristics, Corporate governance, CSR and Organization Learning and Growth} The results of the analysis done to establish the joint effect of TMT characteristics, corporate governance, and CSR on organizational learning and growth are presented in table 6.

Table 6: Joint effect of TMT Characteristics, Corporate governance and CSR on Learning and Growth

\begin{tabular}{|c|c|c|c|c|c|c|c|c|}
\hline \multicolumn{9}{|c|}{ Model Summaryb } \\
\hline Model & $\mathrm{R}$ & R Square & \multicolumn{2}{|c|}{$\begin{array}{l}\begin{array}{l}\text { Adjusted } \mathrm{R} \\
\text { Square }\end{array} \\
\end{array}$} & $\begin{array}{l}\text { Std. Error of the } \\
\text { Estimate }\end{array}$ & \multicolumn{3}{|c|}{ Durbin-Watson } \\
\hline 1 & $.578^{\mathrm{a}}$ & .334 & \multicolumn{2}{|l|}{.294} & .62043 & \multicolumn{3}{|l|}{1.631} \\
\hline \multicolumn{9}{|c|}{ a. Predictors: (Constant), Corporate_Governance, Corporate_Social_Responsibility, TMT_characteristics } \\
\hline \multicolumn{9}{|c|}{ b. Dependent Variable: Learning_growth_perspective } \\
\hline \multicolumn{9}{|c|}{ 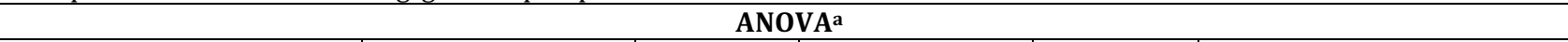 } \\
\hline \multicolumn{2}{|l|}{ Model } & \multicolumn{2}{|c|}{ Sum of Squares } & $\mathrm{df}$ & \multirow{2}{*}{$\begin{array}{r}\text { Mean Square } \\
3.217\end{array}$} & \multirow{2}{*}{$\frac{F}{8.358}$} & \multicolumn{2}{|c|}{ Sig. } \\
\hline \multirow[t]{3}{*}{1} & Regression & \multicolumn{2}{|c|}{9.652} & 3 & & & \\
\hline & Residual & \multicolumn{2}{|c|}{19.247} & 50 & \multirow[t]{2}{*}{.385} & & & $.000^{\circ}$ \\
\hline & Total & \multirow{2}{*}{\multicolumn{2}{|c|}{$\frac{28.899}{\text { ning_growth_perspect }}$}} & 53 & & & & \\
\hline \\
\hline & & & & \multicolumn{5}{|c|}{ b. Predictors: (Constant), Corporate_Governance, Corporate_Social_Responsibility, TMT_characteristics } \\
\hline & & & & Coeff & fficients ${ }^{\mathbf{a}}$ & & & \\
\hline \multirow[t]{2}{*}{ Model } & & & \multicolumn{3}{|c|}{ Unstandardized Coefficients } & \multirow{2}{*}{$\begin{array}{c}\begin{array}{c}\text { Standardized } \\
\text { Coefficients }\end{array} \\
\text { Beta } \\
\end{array}$} & $\mathrm{t}$ & \multirow[t]{2}{*}{ Sig. } \\
\hline & & & \multicolumn{2}{|r|}{ B } & Std. Error & & & \\
\hline \multirow[t]{4}{*}{1} & (Constant) & & & 1.818 & .957 & & 1.900 & .063 \\
\hline & TMT_charac & tics & & -.114 & .357 & -.053 & -.319 & .751 \\
\hline & Corporate_S & I_Responsibility & & .576 & .161 & .533 & 3.580 & .001 \\
\hline & Corporate_G & rnance & & .120 & .205 & .109 & .586 & .560 \\
\hline
\end{tabular}


Table 6 shows the results of the joint effect of TMT characteristics, CSR and corporate governance had a moderate positive relationship $(\mathrm{R}=0.578)$ on learning and growth perspective and explain 33.4 percent of variation on learning and growth perspective of large manufacturing firms $\left(\mathrm{R}^{2}=0.334\right)$. The $\mathrm{F}$ statistic of this model was 8.358 and $p$ value was 0.000 . The $p$ value $.000<0.05$, means the model is statistically significant at 95 percent confidence level.

\section{CONCLUSION}

The focal objective of the study was to establish the synergistic effect of TMT characteristics, corporate governance and CSR on performance of manufacturing firms. It was established that a strong positive relationship $\mathrm{R}=0.686$ which was statistically significant existed. The analysis of variance results for regression coefficients indicates an F statistic of 14.786 with a significance level of $.000<0.05$ hence implying that there is a significant relationship between joint TMT characteristics, corporate governance, CSR and organizational performance. Corporate governance contributes more to performance, Beta value $=0.436$ followed by CSR with Beta value $=0.326$. However, TMT characteristics contributes negatively with Beta value $=-$ 0.270. The results indicate that TMT characteristics, corporate governance and CSR jointly explained 47 percent of the variance in organizational performance $\left(R^{2}=0.470\right)$, the effect was statistically significant at .000 being less than the threshold of $.005(\mathrm{p}<0.001)$. Further analyses were done to test the synergy of TMT characteristics, corporate governance and CSR on individual perspectives of organizational performance. The results show that the joint effect had a positive moderate relationship $(\mathrm{R}=0.514)$ on financial performance and explained 26.5 percent of variation in financial performance of large manufacturing firms ( $\mathrm{R}$ squared $=0.265$ ) and was statistically significance at $.002<0.05$. Secondly, the results show that joint effect had a strong positive relationship $(\mathrm{R}=0.546)$ on customer service and explains 29.9 percent of customer service of large manufacturing firms (R squared $=0.299$ ) with a significance level of $.001<0.05$. Thirdly, the results show that joint effect had a strong positive relationship $(\mathrm{R}=$ 0.666) on internal business processes and explains 44.3 percent of internal business processes of large manufacturing firms (R squared $=0.443$ ) with a significance level of $.000<0.05$. Lastly, the results show that joint effect had a strong positive relationship $(\mathrm{R}=0.578)$ on learning and growth perspective and explains 33.4 percent of learning and growth of large manufacturing firms in Kenya (R squared $=0.334$ ), and is statistically significant ( $\mathrm{p}$-value $0.000<0.05$ ).

The findings of the study showed that TMT characteristics, corporate governance and CSR were present to a great extent within large manufacturing firms. The study findings agrees with Mutuku, K'Obonyo, and Awino (2013) posit that TMT characteristics have the potential to result in effective strategic decision making, greater creativity, more innovation and ability to reach more and different types of stakeholders, which in effect positively impact on firm performance. The results agree with Keong (2002) who points out that good corporate the company's resources increasing corporate performance. Other previous studies have proved positive relationship between CSR and consumer confidence (Swaene, 2001), differentiation of firm products (McWilliams \& Siegel, 2001), improvement in company reputation and image (Kramer et al. 2006) and ability to attract, motivate and retain employees (Kottler et al. 2005) all of which have been supported by the results of this study. The results further supports the Balanced Scorecard model for assessing performance. It blends past financial performance with methods that stimulate long-term success. YIP et al. (2009) advocates for the need of financial measures being balanced by including non-financial measures that factor in customer satisfaction, employee morale, internal business processes and learning and growth perspectives. The researchers concluded that all variables of this study are key contributors to synergy and all synergy is positive and the concept of synergy was found to be direct. 
Organizational performance is a multidimensional element requiring contribution from TMT characteristics, corporate governance and CSR, addition of more factors should be considered in future studies.

When hiring top managers, boards might need to match the characteristic profiles of candidates against the members of the existing management team. Firms attain superior performance if they incorporated good corporate governance with an independent board chairman, specialized board committees, and more outside directors on their boards. Organizations should mainstream CSR practices that are consistent with expected societal expectations to stimulate higher performance. Recognizing that the Kenyan government anticipates major contribution from manufacturing in reducing unemployment, increasing GDP, attracting foreign investment upping its position in ease of doing business ranking, policies should be put in place to support manpower development, encourage improvement in governance and emphasize moral organizational value system. Policy makers are encouraged to appreciate the institutional forces that impact on manufacturing performance in the Kenyan context as they formulate policies to aid competiveness of the sector projected in Kenya Vision 2030.

\section{References}

Amihud, Y., Lev, B. (1981). Risk reduction as a managerial motive for conglomerate mergers. Bell Journal of Economics 12: 605-617.

Boyd, B.K., (1994) Board control and CEO compensation. Strategic Management Journal, 15 (1994), pp. 335-344

Dalton, D. R., Daily, C. M, Ellstrand, \& A. E, Johnson, J. L. (1998). Meta-analytic reviews of board composition, leadership structure, and financial performance. Strategic Management Journal 19 (3): 269 - 290.

Dalton, D. R., Hitt, M. A., Certo, S. T. \& Dalton, C. M. (2007). 'The fundamental agency problem and its mitigation: independence, equity and the market for corporate control'. Academy of Management Annals, 1, 1-64.

Eisenhardt, K. M., (1989). Building Theories from Case Study Research The Academy of Management Review Vol. 14, No. 4 (Oct., 1989), pp. 532-550

Finkelstein, S., \& Hambrick, D. C. (1996). Strategic Leadership: Top Executives and their Effects on Organizations. Minneapolis, West Publishing.

Freedman, M. \& Stagliano, A. (1991).Differences in Social Cost Disclosures: A Market Test of Investor Reaction. Accounting, Auditing and Accountability Journal, 4 (1), 68- 83.

Godfrey, M., Townsend, J. and Denby, T. (2004) Building a good life for older people in local communities: The experience of ageing in time and place, York: Joseph Rowntree Foundation.

Hambrick, D. C. \& Mason, P. A. (1984). Upper Echelon: The Organization as a Reflection of its Top Managers. Academy on Management Review, 9, 193-206.

Hofer, C. W., \& Schendel, D. Strategy formulation: Analytical concepts. St. Paul, MN: West, 1978.

Jo, H. and Harjoto, M. (2011) 'Corporate governance and firm value: The impact of Corporate social responsibility', Journal of Business Ethics, 103(3): 351-83.

Keong, L.C. (2002). Corporate governance: An Asia-Pacific Critique. Hong Kong, Sweet \& Maxwell Asia.

Kramer, V. W., Konrad, A. M., \& Erkut, S. (2006). Critical mass on corporate boards: why three or more women enhance governance (pp. p.74): Wellesley Centers for Women, Wellesley College.

Lepak, D., Susan, M., Tekleab, Amanuel, Marrone, A.J., \& Cohen, D. (2007). An examination of the use of highinvestment human resource systems for core and support employees. Human Resource Management. 46. 223-246. 10.1002/hrm.20158.

Li-Jen He, Chao-Jung Chen and Hsiang - Tsai Chiang. (2015). Top Manager Background Characteristics, Family Control and Corporate social responsibility (CSR) Performance Journal of Applied Finance \& Banking, vol. 5, no. 1, 2015, 71-86ISSN: 1792-6580 (print version), 1792-6599 (online)Scienpress Ltd, 2015.

Margolis, J. D, Walsh JP (2003) Misery loves companies: Rethinkingsocial initiatives by business.Admin. Sci. Quart.48:268-305. 
McWilliams, A. \& Siegel, D. (2001). Corporate social responsibility: A Theory of the Firm Perspective. Academy of Management Review, 26, 117-127.

Monks, A. G. \& Minow, N. 2001. Corporate governance. $2^{\text {nd }}$ edition. Malden, MA: Blackwell Business.

Mutuku, C., K'Obonyo P, Awino, Z.B. \& Musyoka, M. (2013). Top management team diversity, involvement culture and performance of commercial banks in Kenya. DBA Africa Management Review, 3(2), 70-80.

Shafer, W., K. Fukukawa., and G. Lee. (2007). Values and the Perceived Importance of Ethics and Social Responsibility: The U.S. versus China. Journal of Business Ethics 70(3): 265-284.

Shane, P., Spicer, B. (1983). Market response to environmental information produced outside the firm. Accounting Review, 58 (3), 521-538.

Sherer, P.D. \& Leblebici, H. (2001) Bring variety and change into strategic human resource management research. Research in Personnel and Human Resources Management, 20:199-230.

Swaen, G. G., Teggeler, O. Van Amelsvoort, L. G. False positive outcomes and design characteristics in occupational cancer epidemiology studies. int I Epidemiol. 2001 Oct; 30(5):948-54

Swanson, D.L. (2008). Top managers as drivers for corporate social responsibility. In The Oxford Handbook of Social Responsibility, Eds Crane, McWilliams, Matten, Moon and Siegel. Oxford: Oxford University Press.

Waddock, S. A. \& Samuel B. G. (1997). The Corporate Social Performance Financial Performance Link. Strategic Management Journal, 18 (4), 303-319.

Waldman, D. A., \& Siegel, D. (2008). Defining the socially responsible leader. Leadership Quarterly, 19, $117-131$. 